\title{
Listeria monocytogenes Inhibits Serotonin Transporter in Human Intestinal Caco-2 Cells
}

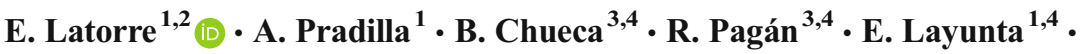 \\ A. I. Alcalde ${ }^{1,4}$ - J. E. Mesonero ${ }^{1,4}$
}

Received: 4 November 2015 / Accepted: 23 June 2016 / Published online: 3 August 2016

(C) The Author(s) 2016. This article is published with open access at Springerlink.com

\begin{abstract}
Listeria monocytogenes is a Gram-positive bacterium that can cause a serious infection. Intestinal microorganisms have been demonstrated to contribute to intestinal physiology not only through immunological responses but also by modulating the intestinal serotonergic system. Serotonin (5HT) is a neuromodulator that is synthesized in the intestinal epithelium and regulates the whole intestinal physiology. The serotonin transporter (SERT), located in enterocytes, controls intestinal 5-HT availability and therefore serotonin's effects. Infections caused by L. monocytogenes are well described as being due to the invasion of intestinal epithelial cells; however, the effect of L. monocytogenes on the intestinal epithelium remains unknown. The main aim of this work, therefore, was to study the effect of L. monocytogenes on SERT. Caco2/TC7 cell line was used as an enterocyte-like in vitro model, and SERT functional and molecular expression assays were performed. Our results demonstrate that living $L$. monocytogenes inhibits serotonin uptake by reducing SERT expression at the brush border membrane. However, neither inactivated
\end{abstract}

A. I. Alcalde In memoriam.

E. Latorre

e.latorre@exeter.ac.uk

1 Departamento Farmacología y Fisiología, Facultad de Veterinaria, Instituto de Investigación Sanitaria de Aragón (IIS), Universidad de Zaragoza, Zaragoza, Spain

2 Present address: RNA-Mediated Mechanisms of Disease, Institute of Biomedical and Clinical Sciences, University of Exeter Medical School, Exeter, UK

3 Departamento de Producción Animal y Ciencia de los Alimentos, Facultad de Veterinaria, Universidad de Zaragoza, Zaragoza, Spain

4 Instituto Agroalimentario de Aragón - IA2, Universidad de Zaragoza - CITA, Zaragoza, Spain
L. monocytogenes nor soluble metabolites were able to affect SERT. The results also demonstrate that $L$. monocytogenes yields TLR2 and TLR10 transcriptional changes in intestinal epithelial cells and suggest that TLR10 is potentially involved in the inhibitory effect observed on SERT. Therefore, L. monocytogenes, through TLR10-mediated SERT inhibition, may induce increased intestinal serotonin availability and potentially contributing to intestinal physiological changes and the initiation of the inflammatory response.

Keywords 5 -HT $\cdot$ SERT $\cdot$ Intestinal epithelium $\cdot$ Listeriosis · TLR

\section{Introduction}

Listeria monocytogenes is a food-borne Gram-positive bacterium that might cause the serious listeriosis infection, particularly in immune-compromised individuals [1]. After the ingestion of food or contaminated water, L. monocytogenes crosses the intestinal barrier by invading intestinal epithelial cells. An effective immune response to L. monocytogenes infection relies on coordinated innate and adaptive immune responses, where the first line of defense is mediated by toll-like receptors (TLRs). However, the activation of innate immunity in response to L. monocytogenes infection is still not fully understood. L. monocytogenes has been shown to be recognized by TLR2 [2], TLR5 [3], and orphan TLR10 [4], without ruling out other immune receptors such as NOD1 [5] or NOD2 [6].

The intestinal epithelium forms a mucosal surface providing a critical barrier function against microbial invasion. Similar to immune cells, intestinal epithelial cells express TLRs and are the first line of bacterial recognition in the intestine [7]. Recent results have demonstrated that bacteria 
resident in the intestinal lumen, through the activation of TLRs, may affect intestinal pathophysiology [8] by acting on the intestinal serotonergic system [9]. Serotonin (5-HT) is a neuromodulator that is mainly synthesized in the intestinal epithelium, and it has been shown to regulate the whole intestinal physiology and to be essential for the maintenance of intestinal homeostasis [10-12]. In fact, the excess of extracellular 5-HT has been described as contributing to intestinal inflammation $[13,14]$. 5-HT activity depends on the extracellular 5-HT availability, which is mainly modulated by the serotonin transporter (SERT) located in the enterocytes. SERT is responsible for the 5-HT uptake into these cells and controls its effects; consequently, SERT takes part in both intestinal homeostasis and inflammatory responses.

Since some studies have demonstrated that the stimulation of different TLRs modulates the intestinal serotonergic system by inhibiting SERT $[15,16]$, the main aim of the present work was to analyze whether L. monocytogenes, a pathogenic microorganism ingested with food, affects intestinal SERT activity and expression. We have used human intestinal epithelial Caco-2/TC7 cells as an in vitro model, since previous studies have shown the suitability of this cellular model to SERT and TLRs investigations [16, 17].

\section{Materials and Methods}

\section{Materials}

The following drugs and substances were used (abbreviations and suppliers in parentheses): serotonin (5-HT) from SigmaAldrich (St. Louis, MO). $\left[{ }^{3} \mathrm{H}\right]-5-\mathrm{HT}$ (specific activity $28 \mathrm{Ci}$ / mmol) was from PerkinElmer (Boston, MA). Goat polyclonal antibody anti-human SERT (ab130130), goat polyclonal antihuman TLR10 (ab53631), and rabbit monoclonal anti-human TLR2 (ab108998) were supplied by Abcam (Cambridge, UK). Goat polyclonal anti-human actin antibody (SC-1616r) and secondary antibodies coupled to horseradish peroxidase were from Santa Cruz Biotechnology (Santa Cruz, CA), and Pepinh-MYD (an inhibitory peptide of MyD88) was from InvivoGen (San Diego, CA). All generic reagents were purchased from Sigma-Aldrich and Roche Applied Sciences (Sant Cugat del Vallés, Barcelona, Spain).

\section{Cell Culture}

Human enterocyte-like cell line Caco-2/TC7 [18] was maintained in high glucose DMEM supplemented with $2 \mathrm{mM}$ glutamine, $100 \mathrm{U} / \mathrm{ml}$ penicillin, $100 \mu \mathrm{g} / \mathrm{mL}$ streptomycin, $1 \%$ non-essential amino acids, and $20 \%$ heat-inactivated fetal bovine serum (FBS) (from Life Technologies, Carlsbad, CA) and cultured in a humidified incubator $37{ }^{\circ} \mathrm{C}$ with $5 \% \mathrm{CO}_{2}$. The cell culture and management has been described elsewhere [17]. The cells were passaged enzymatically (0.25\% trypsin-1 mM EDTA) and subcultured in 25 - or 75$\mathrm{cm}^{2}$ plastic culture flasks and 24-well plates (Sarstedt, Germany). The medium was changed $48 \mathrm{~h}$ after seeding and daily thereafter. Infection experiments were carried out 14 days after seeding, and the cell medium had been free of FBS for $24 \mathrm{~h}$ before the experiment. Caco- 2 cells were seeded in 12well permeable polyester (PET) membranes with porous size $0.4 \mathrm{~mm}$ (Millicell cell culture inserts; Millipore, Billerica, MA, USA) and the growth area was $1 \mathrm{~cm}^{2}$. These inserts established the apical and basal compartments, and the confluence and integrity of the cells were assessed by microscopy (Zeiss Axiovert 200M with AxioCam HRC camera, Carl Zeiss Microimaging, Thornwood, NY) and a determination of transepithelial electrical resistance (TER) by epithelial voltohmmeter (Millicell Electrical Resistance System, Millipore).

\section{Bacterial Culture and Infection of Caco-2/TC7 Cells}

During this study, cultures of L. monocytogenes EGD-e [19] were maintained in cryovials at $-80{ }^{\circ} \mathrm{C}$. A broth subculture was prepared by inoculating a test tube containing $5 \mathrm{~mL}$ of sterile tryptic soy broth (Biolife, Milan, Italy) with a colony from a plate and adding $0.6 \%$ of yeast extract (TSBYE, Biolife). With these overnight subcultures, $250-\mathrm{mL}$ Erlenmeyer flasks containing $50 \mathrm{~mL}$ of TSBYE were inoculated to a final concentration of $10^{5}$ cells $/ \mathrm{mL}$. These flasks were incubated under agitation (130 rpm; Selecta, mod. Rotabit, Barcelona, Spain) at $37^{\circ} \mathrm{C}$ for $6 \mathrm{~h}$ until a cell concentration of $10^{8} / \mathrm{mL}$ was reached. The bacterial culture was subsequently washed with sterile PBS through two steps of centrifugation $(3000 \times g$ for $5 \mathrm{~min}$ ) and diluted in sterile PBS at the desired multiplicity of infection (50-200). Multiplicity of infection (MOI) is the ratio of the number of bacteria to the number of target cells.

To infect Caco-2/TC7 cells, the L. monocytogenes cell population was added to $0.4 \mathrm{~mL}$ of sterile DMEM and supplemented with $2 \mathrm{mM}$ glutamine and $1 \%$ non-essential amino acids and incubated with the Caco-2/TC7 cells at $37^{\circ} \mathrm{C}$ for the periods of treatment ( 1 or $2 \mathrm{~h}$ ). After that, the cell monolayer was treated with freshly prepared gentamicin solution $(50 \mu \mathrm{g} /$ $\mathrm{mL}$ ) for $30 \mathrm{~min}$ to remove adherent bacteria from the cell surface. For studies about bacterial supernatants, an overnight culture supernatant was collected by centrifuging the bacterial culture and then filter-sterilized by passing it through a $0.22-\mu \mathrm{m}$ sterile syringe filter.

For the L. monocytogenes growth analysis, different concentrations of serotonin $\left(10^{-4}\right.$ and $\left.10^{-8} \mathrm{M}\right)$ were prepared in tryptic soy broth. The tubes were then inoculated with L. monocytogenes $\left(10^{5} \mathrm{CFU} / \mathrm{mL}\right)$ and incubated at $37^{\circ} \mathrm{C}$ under agitation. The bacterial count was determined for each tube after $0,1,2,3,4,5,6,7,8$, and $24 \mathrm{~h}$ of incubation. 
Briefly, $100-\mu \mathrm{L}$ culture was obtained for each time point, serially diluted with sterile saline, and samples were pour-plated onto tryptic soy agar (Biolife) and $0.6 \%$ of yeast extract added (TSAYE) as a recovery medium. The plates were incubated for $48 \mathrm{~h}$ at $30{ }^{\circ} \mathrm{C}$. After incubation, colony-forming units (CFU) were counted with an analyzer automatic counter (Protos, Analytical Measuring System, Cambridge, UK). The limit of detection was $10 \mathrm{CFU} / \mathrm{mL}$. Each concentration test was performed in duplicate.

\section{Inactivation of $L$. monocytogenes}

To verify whether the inactivated $L$. monocytogenes would affect SERT, two technologies for bacterial inactivation were used: heat and pulsed electric fields (PEF) treatments. For obtaining heat-inactivated $L$. monocytogenes cells, $1 \mathrm{~mL}$ aliquots were immersed in a water bath at $60{ }^{\circ} \mathrm{C}$ for $1 \mathrm{~h}$. The PEF treatments were carried out using equipment that delivered exponential decay pulses, as previously described [20]. The treatment chamber was made of a cylindrical plastic tube closed with two polished, stainless steel electrodes. The gap between electrodes was $0.25 \mathrm{~cm}$, and the electrode area was $2.01 \mathrm{~cm}^{2}$. Before the treatment, $L$. monocytogenes cells were resuspended in a Mcllvaine citrate-phosphate buffer of $\mathrm{pH} 7.0$, and the electrical conductivity was adjusted to $2 \mathrm{mS} / \mathrm{cm}$ for a final concentration of $10^{7} \mathrm{CFU} / \mathrm{mL}$. Then, $0.5 \mathrm{~mL}$ of the samples was placed into the treatment chamber with a sterile syringe, as it has been previously described. Cell suspensions were treated for 100 pulses $(1 \mathrm{~Hz}$, pulse width $2 \mu \mathrm{s})$ at an electric field strength of $35 \mathrm{kV} / \mathrm{cm}$, corresponding to a specific energy of $8.07 \mathrm{~kJ} / \mathrm{kg}$ per pulse. In PEF experiments, the temperature of the samples was lower than $35^{\circ} \mathrm{C}$. After bacterial inactivation treatments, $0.1 \mathrm{~mL}$ samples were pour-plated onto TSAYE as a recovery medium. The plates were incubated for $48 \mathrm{~h}$ at $37^{\circ} \mathrm{C}$. The inactivation of both L. monocytogenes treatments (at least $5 \log _{10}$ cell cycles) was verified before the infection of the cell culture was carried out.

\section{5-HT Uptake Studies}

5-HT uptake by confluent Caco-2/TC7 monolayers was previously described by our research group [21]. In brief, the cells were incubated with transport medium $(137 \mathrm{mM} \mathrm{NaCl}$, $4.7 \mathrm{mM} \mathrm{KCl}, 1.2 \mathrm{mM} \mathrm{KH}_{2} \mathrm{PO}_{4}, 1.2 \mathrm{mM} \mathrm{MgSO}_{4}, 2.5 \mathrm{mM}$ $\mathrm{CaCl}_{2}, 10 \mathrm{mM}$ HEPES $\mathrm{pH} 7.4,4 \mathrm{mM}$ glutamine, $0.1 \%$ BSA), and both $2 \times 10^{-7} \mathrm{M} 5$-HT and $1.5 \mu \mathrm{Ci} / \mathrm{ml}\left[{ }^{3} \mathrm{H}\right]-5$-HT at $37^{\circ} \mathrm{C}$ for $6 \mathrm{~min}$, and the uptake reaction was terminated by the twice addition of ice-cold substrate-free transport medium containing $2 \times 10^{-4} \mathrm{M} 5$-HT. The cells were lysed with $0.1 \mathrm{~N}$ $\mathrm{NaOH}$ and then were analyzed for radioactivity in a liquid scintillation counter (Wallac Liquid Scintillation Counter, PerkinElmer). The total protein was measured using the Bradford method (Bio-Rad, Hercules, CA) with BSA protein as standard. The results were calculated in pmol 5-HT/mg protein and expressed as a percentage of the control value $(100 \%)$.

To analyze the involvement of TLR2 and TLR10 in the effects of L. monocytogenes effects on 5-HT uptake, TLR blocking was assessed. To do so, SERT activity was measured in cells pretreated with TLR 2 or TLR 10 antibodies at $1 \mu \mathrm{g} / \mathrm{mL}$ for $30 \mathrm{~min}$ prior to the L. monocytogenes infection (MOI 200) and then with the corresponding antibody for $2 \mathrm{~h}$.

\section{Real-Time PCR Analysis}

Total RNA was isolated from confluent Caco-2/TC7 cells cultured in $25-\mathrm{cm}^{2}$ flaks using an RNeasy mini kit (Qiagen, Hilden, Germany) and following the manufacturer's instructions as previously described [22]. The extracted RNA $(1 \mu \mathrm{g})$ was used as a template for first-strand cDNA synthesis using oligo $(\mathrm{dT})$ primers and a reverse transcriptase (Life Technologies). Reactions were run using the StepOnePlus Real-Time PCR System (Life Technologies) with GAPDH and HPRT1 housekeeping gene expression used as a calibrator. The primers used were HPRT 1 sense (5' CTGACCTGCTGGATTACA $3^{\prime}$ ) and HPRT1 antisense (5' GCGACCTTGACCATCTTT 3'), GADPH sense (5' CATGACCACAGTCCATGCCATCACT $3^{\prime}$ ) and GADPH antisense (5' TGAGGTCCACCACCCTGTTGCTGTA 3'), TLR2 sense (5' GAAGCTCCAGCAGGAACATC $3^{\prime}$ ) and TLR2 antisense ( $5^{\prime}$ GAATGAAGTCCCGCTT ATGAAGACA $3^{\prime}$ ), TLR10 sense (5' TTGCATTCCCACC AGGTATC $3^{\prime}$ ) and TLR10 antisense (5' AGCCCACATTTA CGCCTATC $3^{\prime}$ ), and SERT sense (5' 5AAATCCAAG CACCCAGAGAT 3') and SERT antisense (5' AGACT GTGTCCCTGTGGAGA $3^{\prime}$ ). Each sample was run in triplicate, and the mean $\mathrm{Ct}$ was determined. The relative gene mRNA expression under each experimental condition (control or treatment) was expressed as $\Delta \mathrm{Ct}\left(=\mathrm{Ct}_{\text {gene }}-\mathrm{Ct}_{\text {calibrator }}\right)$, and the relative gene mRNA expression was calculated as $\Delta \Delta \mathrm{Ct}$ $\left(=\Delta \mathrm{Ct}_{\text {control }}-\Delta \mathrm{Ct} \mathrm{t}_{\text {treatment }}\right)$. Finally, the relative gene expression levels were converted and expressed as a fold difference $\left(=2^{-\Delta \Delta \mathrm{Ct}}\right)$.

\section{Brush Border-Enriched Fraction from Caco-2/TC7 Cells and Western Blotting}

The enriched fraction of the intestinal brush border was prepared following the procedure previously described [23]. The brush border-enriched fraction and the cell lysate $(60 \mu \mathrm{g}$ of total protein) from Caco-2/TC7 cells were electrophoresed in $8 \%$ SDS-PAGE gels and then transferred to PVDF membranes by electroblotting. The membranes were blocked with $5 \%$ nonfat dried milk plus $1 \%$ BSA and probed using a specific primary antibody (anti-SERT 1:500, anti-TLR2 1:1000, and anti-TLR10 1:1000). The primary antibody was 
detected using a secondary antibody coupled to horseradish peroxidase and the WesternBright Sirius Kit (Advansta, Menio Park, CA) and was visualized with VersaDoc (Imaging System, Bio-Rad). The blots were reprobed after stripping, with goat polyclonal anti-human $\beta$-actin used to determine differences in the sample load. The specific protein/ $\beta$-actin protein ratio was calculated in densitometric units from the film with Quantity One Analysis Software (Bio-Rad), and the results were expressed as a percentage of the control values.

\section{Statistical Analysis}

All results are expressed as mean \pm the standard error of the mean (SEM). Statistical comparisons were performed by oneway ANOVA followed by the Bonferroni posttest with a confidence interval of $95 \%(P<0.05)$. The normal distribution has been previously confirmed with the D'Agostino-Pearson test. The statistical analysis was carried out with the computerassisted GraphPad Prism Program (Prism version 4.0, GraphPad Software, San Diego, CA).

\section{Results}

\section{L. monocytogenes Inhibits 5-HT Uptake}

To determine if L. monocytogenes affects 5-HT uptake, the Caco-2/TC7 monolayer was first studied; the confluence and integrity of the cells after $L$. monocytogenes infection were assessed by microscopy and by determining the TER. The infection of $L$. monocytogenes at the maximum concentration used in this study (MOI 200 or 200 bacteria per cell) for $2 \mathrm{~h}$ did not affect neither the morphology nor the TER of the cell monolayer (data not shown). Next, we examined the effect of L. monocytogenes on the 5-HT uptake for 1 and $2 \mathrm{~h}$ at different MOIs $(50,100$, and 200). The results showed that L. Monocytogenes causes a significant inhibition of 5-HT uptake and that this inhibition is bacterial load-dependent for the 1-h infection; however, for the 2-h infection, the same reduction was observed at different MOIs (Fig. 1a).

To characterize the SERT inhibition by L. monocytogenes, we examined the effect of treated Caco-2/TC7 monolayers with inactivated L. monocytogenes. Initially, L. monocytogenes was inactivated by heat; however, the results obtained showed that this was not able to affect SERT activity (Fig. 1b).

Extending this result, heat could damage to most microbial structures and components, limiting their effects on SERT activity. Thus, a different inactivation technology that is less harmful to microbial structures was used. To this end, PEF treatment, a less aggressive method that is known to only affect cell envelopes, was used [20]. The results showed that
L. monocytogenes inactivated by PEF was not able to affect SERT (Fig. 1c).

We also examined the effect of $L$. monocytogenes culture supernatant to evaluate its ability to produce toxins that could affect 5-HT uptake. The results showed that no effect of L. monocytogenes supernatant on 5-HT uptake, indicating that only living $L$. monocytogenes cells seem to affect SERT activity (Fig. 1d).

\section{The Effects of $L$. monocytogenes on SERT Molecular Expression}

To analyze the effects of $L$. monocytogenes on SERT activity in more depth, SERT molecular expression was assessed. Thus, SERT mRNA and protein levels were measured in Caco-2/TC7 cells that had been treated for $2 \mathrm{~h}$ with MOI 200. The results showed that L. monocytogenes infection decreases SERT mRNA level (Fig. 2a). In relation to SERT protein analysis, the results showed that SERT was significantly diminished in the brush border of cells infected with L. monocytogenes; however, the SERT protein level in the whole cell homogenate was not modified (Fig. 2b, c).

\section{The Role of MyD88 on L. monocytogenes Effects on SERT Function}

TLRs have been clearly established as the major sensors of the innate immune system, and they seem to play a key role in immunity against L. monocytogenes infection. MyD88 is a universal adapter protein used by most of TLRs to start their effects. Thus, to clarify the effects of L. monocytogenes on SERT, the role of MyD88 was analyzed. SERT activity was measured in cells treated with Pepinh-MYD (an inhibitory peptide of MyD88) plus a L. monocytogenes infection. The results showed that MyD88 inhibition did not alter 5-HT uptake in control conditions; however, MyD88 blocking significantly increased the inhibitory effect of $L$. monocytogenes on 5-HT uptake (Fig. 3).

\section{Involvement of TLR2 and TLR10 in the Effects of L. monocytogenes on SERT}

As recent studies have postulated that both TLR2 and TLR10 play a key role in the inflammatory response against L. monocytogenes [4] and in order to clarify the previous results, the involvement of TLR2 and TLR10 was studied. TLR's role was analyzed by blocking TLR 2 or TLR10 with specific antibodies. To do so, SERT activity was measured in cells pretreated with the TLR 2 antibody at $1 \mu \mathrm{g} / \mathrm{mL}$ for $30 \mathrm{~min}$ prior to a L. monocytogenes infection (MOI 200) along with the TLR2 antibody for $2 \mathrm{~h}$. The results showed that the TLR2 blocking did not modify the inhibitory effect of 

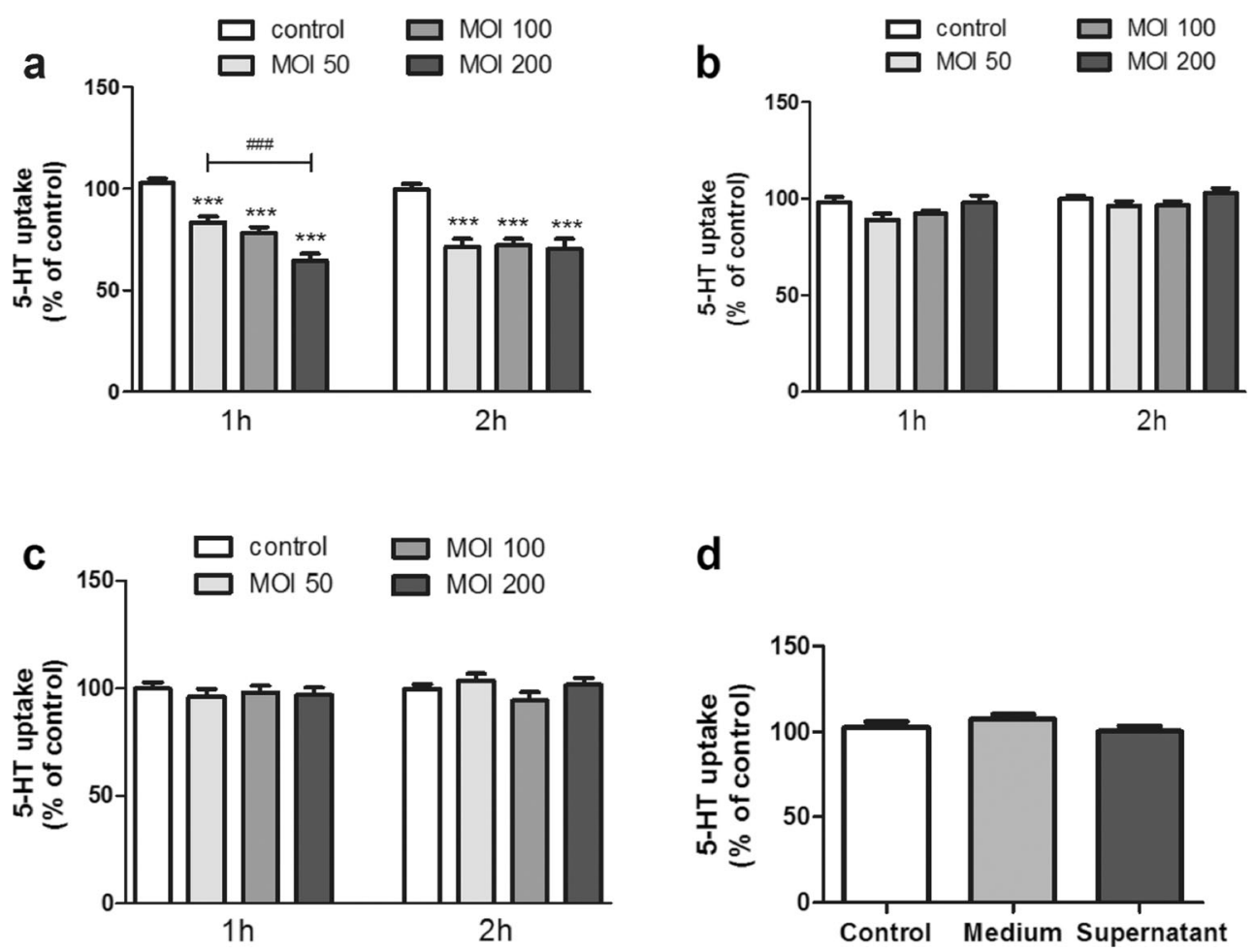

Fig. 1 L. monocytogenes effects on 5-HT uptake. Cells were infected with alive or inactivated L. monocytogenes at MOI 50, 100, and 200 for 1 or $2 \mathrm{~h}$. 5-HT uptake was measured after 6 min incubation with $0.2 \mu \mathrm{M}$ 5-HT. Control condition corresponds to untreated cells. a Effect of live L. monocytogenes on 5-HT uptake. The results are expressed as the percentage of the uptake control and are the mean $\pm \mathrm{SE}$ of six biological replicates in seven independent experiments $(n=42) .{ }^{* * *} P<0.001$ compared with the control. b Effect of heat-killed $L$. monocytogenes on 5-HT uptake. The results are expressed as the percentage of

L. monocytogenes on 5-HT uptake, so TLR2 does not seem to be involved in the effects of $L$. monocytogenes on SERT activity (Fig. 4a). Interestingly, the L. monocytogenes infection affected TLR 2 expression by decreasing both TLR2 mRNA and protein (Fig. 4b, c).

Regarding TLR10, we first described TLR10 expression in our cell model by analyzing mRNA and protein expression (data not shown), as the expression of TLR10 was unknown in Caco-2/TC7 cells. Then, TLR10 involvement was analyzed by blocking TLR 10 with a specific antibody $(1 \mu \mathrm{g} / \mathrm{mL}$ for $30 \mathrm{~min}$ before the infection with L. monocytogenes MOI 200 along with the TLR10 antibody for $2 \mathrm{~h}$ ), and 5-HT uptake was analyzed. The results showed that the effect of L. monocytogenes on SERT was reversed by blocking TLR10, suggesting that this TLR could mediate the effects of L. monocytogenes on SERT activity (Fig. 5a). Moreover, Caco-2/TC7 cells infected with $L$. monocytogenes seemed to present an altered TLR10 expression. Indeed, the results showed that L. monocytogenes causes a decrease in the TLR10 mRNA level; however, the TLR10 protein level did not seem to be modified (Fig. 5b, c), possibly due to the short time of infection.

the uptake control and are the mean $\pm \mathrm{SE}$ of six biological replicates in seven independent experiments $(n=42)$. c Effect of $L$. monocytogenes inactivated by PEF on 5-HT uptake. The results are expressed as the percentage of the uptake control and are the mean $\pm \mathrm{SE}$ of three biological replicates in four independent experiments $(n=12)$. d Effect of L. monocytogenes supernatant on 5-HT uptake. The results are expressed as the percentage of the uptake control and are the mean $\pm \mathrm{SE}$ of three biological replicates in four independent experiments $(n=12)$

\section{The Effects of 5-HT on L. monocytogenes Growth}

Our results demonstrate that $L$. monocytogenes inhibits SERT. Consequently, this effect may trigger an increase of extracellular 5-HT availability in the intestinal lumen, which in turn may yield possible feedback on $L$. monocytogenes. To study this hypothesis, L. monocytogenes growth was evaluated by adding increasing concentrations of 5-HT to the bacterial medium. As a physiological condition, 5-HT $10^{-8} \mathrm{M}$ was used, and as an inflammatory condition, 5-HT $10^{-4} \mathrm{M}$ was used. The results showed that 5-HT (at any concentration assayed) did not seem to modify L. monocytogenes growth (Fig. 6).

\section{Discussion}

Understanding host-microbe interaction in the intestinal tract may provide new insights into intestinal homeostasis and inflammation. Recent studies have demonstrated that some gut microbes can modulate serotonergic system expression, promote 5-HT biosynthesis from enterochromaffin cells, and directly produce or release serotonin $[24,25]$, consequently 


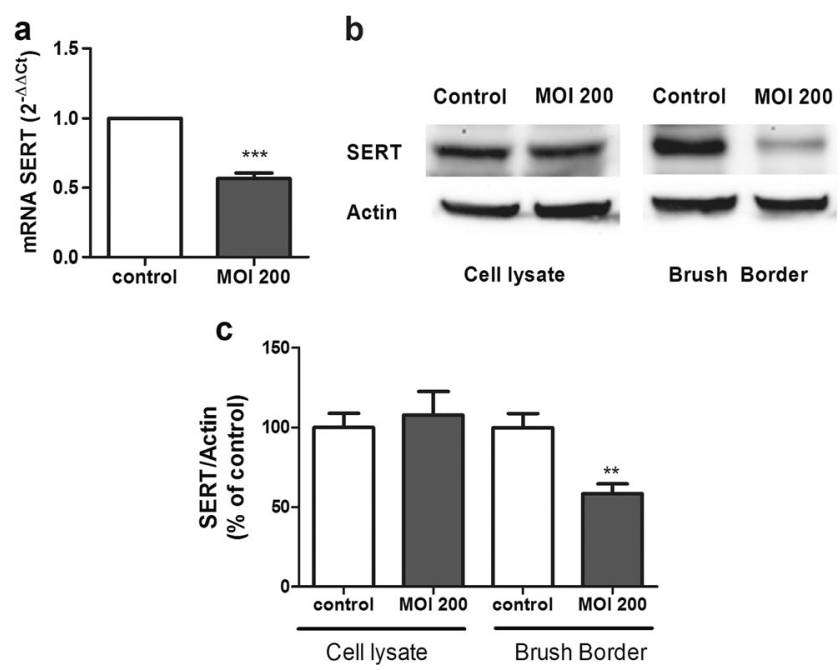

Fig. 2 L. monocytogenes inhibit SERT mRNA and protein expression. a Quantitative RT-PCR analysis of SERT mRNA expression in cells infected with L. monocytogenes for $2 \mathrm{~h}$ at MOI 200. Relative quantification was performed using comparative $\mathrm{Ct}\left(2^{-\Delta \Delta \mathrm{Ct}}\right)$ of three biological replicates in five independent experiments $(n=15)$. Results are expressed as arbitrary units of control $=1 .{ }^{* * *} P<0.001$ compared with the control value. b Immunodetection of SERT by western blot in cell lysate and brush border from Caco-2/TC7 cells infected with L. monocytogenes for $2 \mathrm{~h}$ at MOI 200. $\mathrm{c}$ Quantification of SERT protein in both cell lysate and brush border using $\beta$-actin as an internal control of the protein load (SERT/ $\beta$-actin ratio). The results are expressed as a percentage of the control value and are the mean \pm SEM of two biological replicates in five independent experiments $(n=10)$. $* * P<0.01$ compared with the control value

contributing to intestinal homeostasis. Moreover, some TLRs have also been reported to regulate SERT activity and expression $[15,16]$. Therefore, our main aims in this study were to analyze the effects of L. monocytogenes on intestinal SERT activity and expression and to determine the TLRs involved.

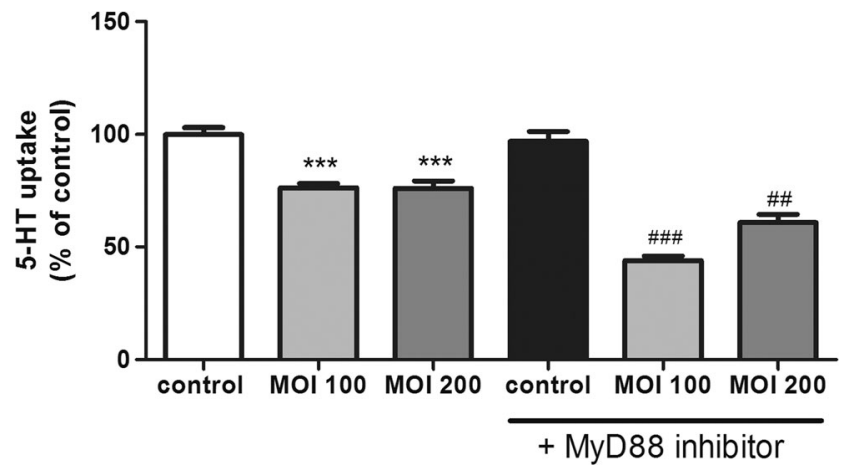

Fig. 3 MyD88 involvement on L. monocytogenes effect on 5-HT uptake. Cells were infected with L. monocytogenes at MOI 100 and 200 for $2 \mathrm{~h}$ and/or MyD88 inhibitor $(100 \mu \mathrm{M} 1 \mathrm{~h}$ previous and during the infection with Listeria) and compared with untreated cells (control). Uptake of 5HT was measured after 6 min of incubation, and 5-HT concentration was $0.2 \mu \mathrm{M}$. The results are expressed as the percentage of the uptake control and are the mean $\pm \mathrm{SE}$ of three biological replicates in four independent experiments $(n=12) .{ }^{*} * *<0.001$ compared with the control. ${ }^{\# \#} P<0.001$ and ${ }^{\# \#} P<0.01$ compared with the corresponding MOI effect without MyD88 inhibitor
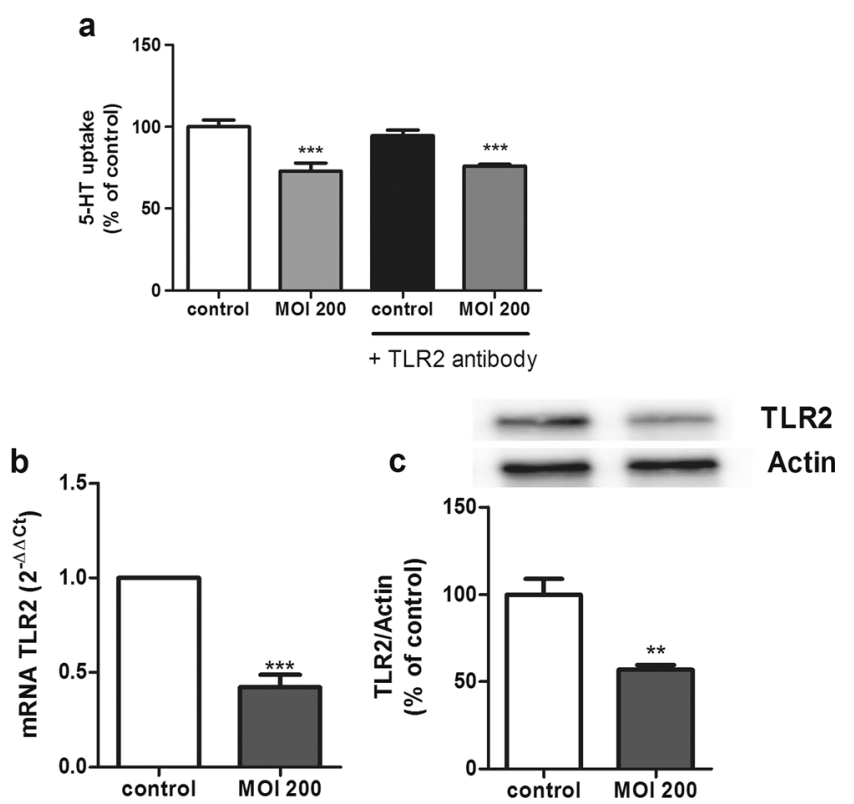

Fig. 4 TLR2 involvement on L. monocytogenes effects. a Cells were infected with L. monocytogenes at MOI 200 for $2 \mathrm{~h}$ and/or TLR2 antibody ( $1 \mu \mathrm{g} 30 \mathrm{~min}$ previous the infection) and compared with untreated cells (control). Uptake of 5-HT was measured after 6 min of incubation, and 5-HT concentration was $0.2 \mu \mathrm{M}$. The results are expressed as the percentage of the uptake control and are the mean $\pm \mathrm{SE}$ of three biological replicates in four independent experiments $(n=12)$. $* * * P<0.001$ compared with the control. b Quantitative RT-PCR analysis of TLR2 mRNA expression in cells infected with $L$. monocytogenes for $2 \mathrm{~h}$ at MOI 200. Relative quantification was performed using comparative $\mathrm{Ct}\left(2^{-\Delta \Delta \mathrm{Ct}}\right)$ of three biological replicates in five independent experiments $(n=15)$. Results are expressed as arbitrary units of control $=1$. $* * * P<0.001$ compared with the control value. $\mathrm{c}$ Expression and quantification of TLR2 protein levels in cell lysate using $\beta$-actin as an internal control of the protein load (TLR $2 / \beta$-actin ratio). The results are expressed as a percentage of the control value and are the mean $\pm \mathrm{SEM}$ of two biological replicates in four independent experiments $(n=8)$. $* * P<0.01$ compared with the control value

Our results showed that living L. monocytogenes cells cause a significant and MOI-dependent reduction of 5-HT uptake for $1 \mathrm{~h}$ of infection, with the maximum effect occurring at MOI 200. The inhibitory effect of $L$. monocytogenes on intestinal 5-HT uptake did appear to require direct contact between living bacteria and the intestinal epithelial cells, as inactivated L. monocytogenes cells and bacterial supernatants did not modify 5-HT uptake. Several studies have shown that entry of $L$. monocytogenes into the cells is dependent on cell polarization and differentiation [26, 27]. In fact, L. monocytogenes is able to invade differentiated polarized Caco-2 cells predominantly through the basolateral surface [26]. Our study was carried out in 14-day-old Caco-2 monolayers, when the cells have reached total confluency and developed enterocyte differentiation [18]. At this culture stage, no basolateral surfaces are accessible to bacteria, and levels of invasion dramatically decrease compared with invasion of non-confluent monolayers [26]. In addition, our results showed not TER change, indicating that the integrity of the 
a

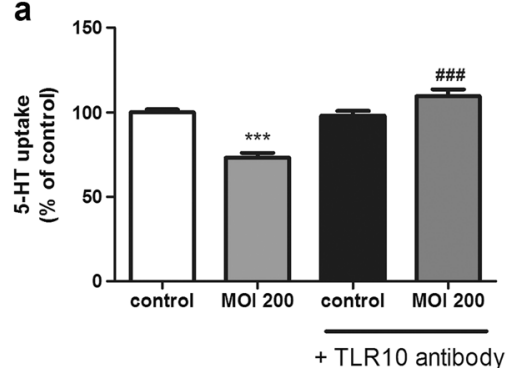

b

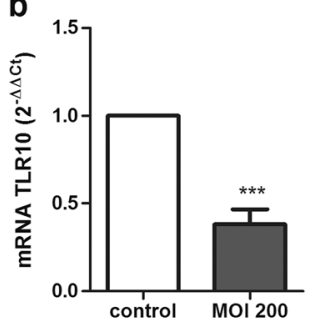

C
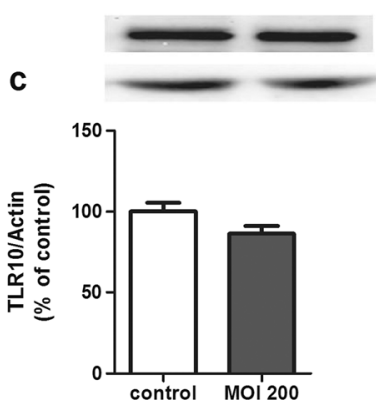

TLR10 Actin

Fig. 5 TLR10 involvement on $L$. monocytogenes effects. a Cells were infected with $L$. monocytogenes at MOI 200 for $2 \mathrm{~h}$ and/or TLR10 antibody $(1 \mu \mathrm{g} 30 \mathrm{~min}$ previous the infection) and compared with untreated cells (control). Uptake of 5-HT was measured after 6 min of incubation, and 5-HT concentration was $0.2 \mu \mathrm{M}$. The results are expressed as the percentage of the uptake control and are the mean $\pm \mathrm{SE}$ of three biological replicates in four independent experiments $(n=12)$. *** $P<0.001$ compared with the control. ${ }^{\# \#} P<0.001$ compared with MOI 200 effect without antibody. b Quantitative RT-PCR analysis of TLR10 mRNA expression in cells infected with L. monocytogenes for $2 \mathrm{~h}$ at MOI 200. Relative quantification was performed using comparative $\mathrm{Ct}\left(2^{-\Delta \Delta \mathrm{Ct}}\right)$ of three biological replicates in five independent experiments $(n=15)$. Results are expressed as arbitrary units of control $=1$. $* * * P<0.001$ compared with the control value. c Expression and quantification of TLR 10 protein in cell lysate using $\beta$-actin as an internal control of the protein load (TLR10/ $\beta$-actin ratio). The results are expressed as a percentage of the control value and are the mean \pm SEM of two biological replicates in four independent experiments $(n=8)$

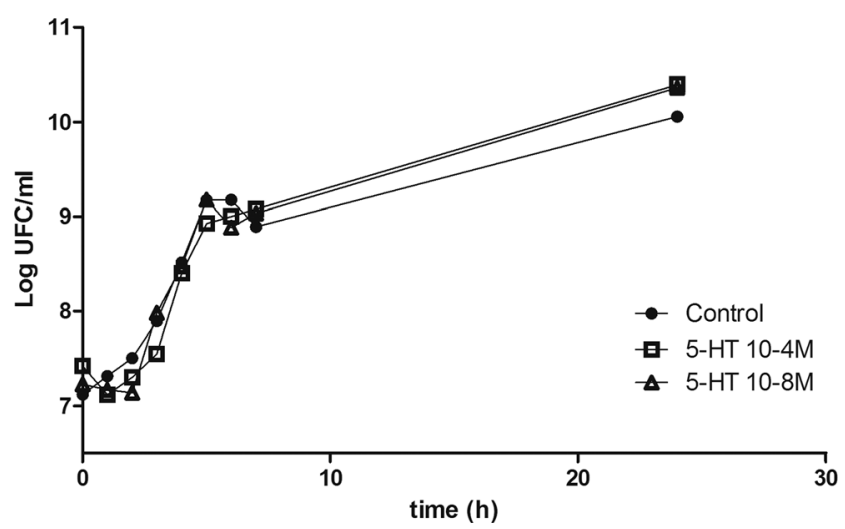

Fig. 6 5-HT effect on growth curve of L. monocytogenes. L. monocytogenes growth was evaluated adding increasing concentrations of 5-HT $10^{-8} \mathrm{M}$ and $10^{-4} \mathrm{M}$ to the bacterial medium from 0 to $24 \mathrm{~h}$. Results are expressed as the mean of three independent experiments in duplicate cell monolayer was undamaged. Then, the observed effect on SERT could be a preliminary result of $L$. monocytogenes prior to intestinal epithelial cells invasion. Nevertheless, we cannot completely discard a possible L. monocytogenes cell invasion.

Our results agree with previous studies that demonstrated the inhibitory effects of living L. monocytogenes on the serotonergic system in the vascular system [27, 28]. However, a recent study has described effects of heat-inactivated L. monocytogenes on the immune response of human monocytic THP-1 cells [29].

The inhibitory effect of $L$. monocytogenes seems to be due to a decrease of SERT protein expression in the brush border cell membrane, which is probably due to posttranslational or posttranscriptional mechanisms. L. monocytogenes yielded a reduction of SERT mRNA; however, only SERT protein expression in the brush border was affected; this could be due to the processing time, as the bacteria are only in contact with the cells for $2 \mathrm{~h}$, so they may need more time to reduce SERT total protein. These results suggest that L. monocytogenes may inhibit SERT activity by reducing SERT protein expression in the brush border for the short term and that, in the long term, this bacterium might reduce SERT protein levels in cell lysate, since it reduces SERT mRNA level. In agreement with these results, other pathogenic bacteria, like $E$. coli, have also been shown to decrease intestinal SERT activity and expression [30].

SERT activity can also be reduced by 5 -HT [22], and some microbes are known to directly produce 5 -HT by themselves [31], so L. monocytogenes could affect SERT in this way; however, L. monocytogenes has not been described as a 5-HT producer.

Regarding the role of MyD88, the results surprisingly showed that MyD88 blocking increases the inhibitory effects of L. monocytogenes, so it seems that L. monocytogenes may activate both a MyD88-dependent (which may increase 5-HT uptake) and a MyD88-independent pathway (which may decrease 5-HT uptake). These results, like other studies, support the hypothesis that L. monocytogenes can activate different pathways, both dependent on and independent of MyD88 [32].

TLRs have been clearly established as the major sensors of the innate immune system, and they seem to play a key role in immunity against L. monocytogenes infection. Although TLR2 [33] and MyD88 [34] have been shown to detect L. monocytogenes infections in other cell types, only NOD2 has been directly shown to mediate the inflammatory response to L. monocytogenes in the intestine [6]. Our investigation of the role of TLRs in L. monocytogenes infection has yielded several observations. TLR2 alone did not seem to play a role in 5-HT uptake in response to L. monocytogenes, but intestinal epithelial cells have shown a TLR2 expression inhibition by L. monocytogenes. Our results disagree with previous results that described a possible relationship between TLR2 and 
L. monocytogenes, although these studies were conducted in immune cells $[35,36]$.

In this study, the results indicated that TLR10 may play a role in the effects of L. monocytogenes on intestinal SERT activity. The highest level of TLR10 expression has been reported in immune cells [37, 38], but TLR10 mRNA and protein expression have previously been shown in human intestinal epithelial cell lines, such as SW480 and HT-29 [4, 39]. Polarized expression of TLRs is a common mechanism for preventing unnecessary and potentially detrimental inflammatory response to bacteria. Differential TLR expression is observed in intestinal epithelial cells depending on the local commensal flora. Generally, TLR1 to TLR10 has been reported on the cell apical side, but only a low constitutive expression of TLR2, TLR4, and TLR5 has been observed on the cell basolateral side [40]. Our study has demonstrated TLR10 expression in the Caco-2/TC7 cell line, indicating a possible functional role in the intestinal epithelium. Although the TLR10 signaling pathway remains unknown, TLR10 expression is located in the cell membrane and has a very strong structural association with TLR1 and TLR6, both of which are heterodimeric with TLR2 [41]. Some studies have suggested a possible TLR2/TLR10 dimer in response to L. monocytogenes [4, 42], but this hypothesis disagrees with our results, as TLR10 blocking is enough to reverse the effect of L. monocytogenes on SERT activity. However, supporting our results, a recent study has suggested a possible TLR10/ TLR10 dimer [42].

TLRs have been described as being activated by pathogenassociated molecular patterns (PAMPs). Each TLR has different PAMPs to be activated, for instance TLR4 detects LPS from Gram-negative bacteria and TLR2 recognizes lipoteichoic acid from Gram-positive bacteria. However, TLR10 agonist is still unknown. Our results suggest that TLR10 could be activated in a different way, as only living L. monocytogenes seems to have effects on SERT. A recent hypothesis has indicated that some TLRs can detect microbial viability using vita-PAMPs, a special class of PAMPs that recognize microbial life [43, 44]; thus, TLR10 may be a receptor for microbial viability and the TLR10 ligand could be a vita-PAMP. In support of this hypothesis, recent studies have demonstrated TLR10's effects only with living bacteria [4, 45].

Regarding a possible feedback, our results demonstrated that 5-HT does not alter L. monocytogenes growth. These results are in agreement with recent studies, which have described that 5-HT does not modify microbial growth; however, 5-HT could alter microbial virulence behavior and change the composition of the intestinal microbiota [46, 47].

In summary, our study demonstrates for the first time that only living $L$. monocytogenes cells lead to a significant reduction in 5-HT uptake in human intestinal epithelial cells and that this inhibitory effect can be mediated through TLR10.
The present work contributes to the understanding of intestinal serotonergic responses induced by gut microbes.

Acknowledgments We are grateful to Dr. Brot-Laroche (INSERM, UMR S 872, Centre de Recherches de Cordeliers, Paris) for providing the Caco-2/TC7 cell line and to Prof. Chakraborty (Institute for Medical Microbiology, Giessen, Germany) for providing L. monocytogenes EGDe. We would like to acknowledge Dr. Grasa for her invaluable advice on this manuscript.

This work was funded by grants from the Spanish Ministry of Science and Innovation and the European Regional Development Fund (ERDF/FEDER) (BFU2010-18971), Zaragoza University (UZ2014BIO-03), European Social Found (ESF), and the Aragon Regional Government (B61) and the Foundation for the Study of Inflammatory Bowel Diseases in Aragón (ARAINF 2012/0567). E. Latorre and E. Layunta are $\mathrm{PhD}$ student fellows from Aragon Regional Government (B105/11 and B022/13).

\section{Compliance with Ethical Standards}

Competing Interests The authors declare that they have no conflicts of interest.

Open Access This article is distributed under the terms of the Creative Commons Attribution 4.0 International License (http:// creativecommons.org/licenses/by/4.0/), which permits unrestricted use, distribution, and reproduction in any medium, provided you give appropriate credit to the original author(s) and the source, provide a link to the Creative Commons license, and indicate if changes were made.

\section{References}

1. Pamer EG (2004) Immune responses to Listeria monocytogenes. Nat Rev Immunol 4(10):812-823. doi:10.1038/nri1461

2. Machata S, Tchatalbachev S, Mohamed W, Jansch L, Hain T, Chakraborty T (2008) Lipoproteins of Listeria monocytogenes are critical for virulence and TLR2-mediated immune activation. J Immunol 181(3):2028-2035

3. Hayashi F, Smith KD, Ozinsky A, Hawn TR, Yi EC, Goodlett DR, Eng JK, Akira S, Underhill DM, Aderem A (2001) The innate immune response to bacterial flagellin is mediated by Toll-like receptor 5. Nature 410(6832):1099-1103. doi:10.1038/35074106

4. Regan T, Nally K, Carmody R, Houston A, Shanahan F, Macsharry J, Brint E (2013) Identification of TLR10 as a key mediator of the inflammatory response to Listeria monocytogenes in intestinal epithelial cells and macrophages. J Immunol 191(12):6084-6092. doi:10.4049/jimmunol.1203245

5. Mosa A, Trumstedt C, Eriksson E, Soehnlein O, Heuts F, Janik K, Klos A, Dittrich-Breiholz O, Kracht M, Hidmark A, Wigzell H, Rottenberg ME (2009) Nonhematopoietic cells control the outcome of infection with Listeria monocytogenes in a nucleotide oligomerization domain 1-dependent manner. Infect Immun 77(7):29082918. doi:10.1128/IAI.01068-08

6. Kobayashi KS, Chamaillard M, Ogura Y, Henegariu O, Inohara N, Nunez G, Flavell RA (2005) Nod2-dependent regulation of innate and adaptive immunity in the intestinal tract. Science 307(5710): 731-734. doi:10.1126/science.1104911

7. Zhang K, Hornef MW, Dupont A (2015) The intestinal epithelium as guardian of gut barrier integrity. Cell Microbiol. doi:10.1111 /cmi.12501 
8. Grasa L, Abecia L, Forcén R, Castro M, García de Jalón J, Latorre E, Alcalde A, Murillo M (2015) Antibiotic-induced depletion of murine microbiota induces mild inflammation and changes in tolllike receptor patterns and intestinal motility. Microb Ecol 69. doi: 10.1007/s00248-015-0613-8

9. Forcen R, Latorre E, Pardo J, Alcalde AI, Murillo MD, Grasa L (2015) Toll-like receptors 2 and 4 modulate the contractile response induced by serotonin in mouse ileum: analysis of the serotonin receptors involved. Neurogastroenterol Motil 27(9):1258-1266. doi:10.1111/nmo.12619

10. Hansen MB, Witte AB (2008) The role of serotonin in intestinal luminal sensing and secretion. Acta Physiol (Oxf) 193(4):311-323. doi:10.1111/j.1748-1716.2008.01870.x

11. Salvador MT, Murillo MD, Rodriguez-Yoldi MC, Alcalde AI, Mesonero JE, Rodriguez-Yoldi MJ (2000) Effects of serotonin on the physiology of the rabbit small intestine. Can J Physiol Pharmacol 78(5):359-366

12. Gershon MD (2004) Review article: serotonin receptors and transporters - roles in normal and abnormal gastrointestinal motility. Aliment Pharmacol Ther 20(Suppl 7):3-14. doi:10.1111/j.13652036.2004.02180.x

13. Kim JJ, Wang H, Terc JD, Zambrowicz B, Yang QM, Khan WI (2015) Blocking peripheral serotonin synthesis by telotristat etiprate (LX1032/LX1606) reduces severity of both chemical- and infection-induced intestinal inflammation. Am J Physiol Gastrointest Liver Physiol 309(6):G455-465. doi:10.1152 /ajpgi.00299.2014

14. Margolis KG, Stevanovic K, Li Z, Yang QM, Oravecz T, Zambrowicz B, Jhaver KG, Diacou A, Gershon MD (2014) Pharmacological reduction of mucosal but not neuronal serotonin opposes inflammation in mouse intestine. Gut 63(6):928-937. doi:10.1136/gutjnl-2013-304901

15. Mendoza C, Matheus N, Latorre E, Castro M, Mesonero JE, Alcalde AI (2012) Toll-like receptor 3 activation affects serotonin transporter activity and expression in human enterocyte-like Caco2 cells. Cell Physiol Biochem 30(1):187-198. doi:10.1159 /000339057

16. Mendoza C, Matheus N, Iceta R, Mesonero JE, Alcalde AI (2009) Lipopolysaccharide induces alteration of serotonin transporter in human intestinal epithelial cells. Innate Immun 15(4):243-250. doi: $10.1177 / 1753425909104781$

17. Iceta R, Mesonero JE, Aramayona JJ, Alcalde AI (2006) Molecular characterization and intracellular regulation of the human serotonin transporter in Caco-2 cells. J Physiol Pharmacol 57(1):119-130

18. Chantret I, Rodolosse A, Barbat A, Dussaulx E, Brot-Laroche E, Zweibaum A, Rousset M (1994) Differential expression of sucraseisomaltase in clones isolated from early and late passages of the cell line Caco-2: evidence for glucose-dependent negative regulation. $\mathrm{J}$ Cell Sci 107(Pt 1):213-225

19. Chatterjee SS, Hossain H, Otten S, Kuenne C, Kuchmina K, Machata S, Domann E, Chakraborty T, Hain T (2006) Intracellular gene expression profile of Listeria monocytogenes. Infect Immun 74(2):1323-1338. doi:10.1128/IAI.74.2.13231338.2006

20. Garcia D, Gomez N, Manas P, Condon S, Raso J, Pagan R (2005) Occurrence of sublethal injury after pulsed electric fields depending on the micro-organism, the treatment medium ph and the intensity of the treatment investigated. J Appl Microbiol 99(1):94-104. doi:10.1111/j.1365-2672.2005.02611.x

21. Latorre E, Mendoza C, Matheus N, Castro M, Grasa L, Mesonero JE, Alcalde AI (2013) IL-10 modulates serotonin transporter activity and molecular expression in intestinal epithelial cells. Cytokine 61(3):778-784. doi:10.1016/j.cyto.2013.01.012

22. Iceta R, Mesonero JE, Alcalde AI (2007) Effect of long-term fluoxetine treatment on the human serotonin transporter in Caco-2 cells. Life Sci 80(16):1517-1524. doi:10.1016/j.lfs.2007.01.020
23. Iceta R, Aramayona JJ, Mesonero JE, Alcalde AI (2008) Regulation of the human serotonin transporter mediated by longterm action of serotonin in Caco-2 cells. Acta Physiol (Oxf) 193(1): 57-65. doi:10.1111/j.1748-1716.2007.01793.x

24. Reigstad CS, Salmonson CE, Rainey JF 3rd, Szurszewski JH, Linden DR, Sonnenburg JL, Farrugia G, Kashyap PC (2015) Gut microbes promote colonic serotonin production through an effect of short-chain fatty acids on enterochromaffin cells. FASEB J 29(4): 1395-1403. doi:10.1096/fj.14-259598

25. Yano JM, Yu K, Donaldson GP, Shastri GG, Ann P, Ma L, Nagler CR, Ismagilov RF, Mazmanian SK, Hsiao EY (2015) Indigenous bacteria from the gut microbiota regulate host serotonin biosynthesis. Cell 161(2):264-276. doi:10.1016/j.cell.2015.02.047

26. Gaillard JL, Finlay BB (1996) Effect of cell polarization and differentiation on entry of Listeria monocytogenes into the enterocytelike Caco-2 cell line. Infect Immun 64(4):1299-1308

27. Czuprynski CJ, Balish E (1981) Interaction of rat platelets with Listeria monocytogenes. Infect Immun 33(1):103-108

28. Sibelius U, Schulz EC, Rose F, Hattar K, Jacobs T, Weiss S, Chakraborty T, Seeger W, Grimminger F (1999) Role of Listeria monocytogenes exotoxins listeriolysin and phosphatidylinositolspecific phospholipase $\mathrm{C}$ in activation of human neutrophils. Infect Immun 67(3):1125-1130

29. Shihab PK, Al-Roub A, Al-Ghanim M, Al-Mass A, Behbehani K, Ahmad R (2015) TLR2 and AP-1/NF-kappaB are involved in the regulation of MMP-9 elicited by heat killed Listeria monocytogenes in human monocytic THP-1 cells. J Inflamm (Lond) 12:32. doi:10.1186/s12950-015-0077-0

30. Esmaili A, Nazir SF, Borthakur A, Yu D, Turner JR, Saksena S, Singla A, Hecht GA, Alrefai WA, Gill RK (2009) Enteropathogenic Escherichia coli infection inhibits intestinal serotonin transporter function and expression. Gastroenterology 137(6):2074-2083. doi:10.1053/j.gastro.2009.09.002

31. Clarke G, Stilling RM, Kennedy PJ, Stanton C, Cryan JF, Dinan TG (2014) Minireview: Gut microbiota: the neglected endocrine organ. Mol Endocrinol 28(8):1221-1238. doi:10.1210/me.2014-1108

32. Tam MA, Wick MJ (2009) MyD88 and interferon-alpha/beta are differentially required for dendritic cell maturation but dispensable for development of protective memory against Listeria. Immunology 128(3):429-438. doi:10.1111/j.13652567.2009.03128.x

33. Janot L, Secher T, Torres D, Maillet I, Pfeilschifter J, Quesniaux VF, Landmann R, Ryffel B, Erard F (2008) CD14 works with toll-like receptor 2 to contribute to recognition and control of Listeria monocytogenes infection. J Infect Dis 198(1):115-124. doi:10.1086/588815

34. Edelson BT, Unanue ER (2002) MyD88-dependent but Toll-like receptor 2-independent innate immunity to Listeria: no role for either in macrophage listericidal activity. J Immunol 169(7):3869 3875

35. Torres D, Barrier M, Bihl F, Quesniaux VJ, Maillet I, Akira S, Ryffel B, Erard F (2004) Toll-like receptor 2 is required for optimal control of Listeria monocytogenes infection. Infect Immun 72(4): 2131-2139

36. Shen Y, Kawamura I, Nomura T, Tsuchiya K, Hara H, Dewamitta SR, Sakai S, Qu H, Daim S, Yamamoto T, Mitsuyama M (2010) Toll-like receptor 2- and MyD88-dependent phosphatidylinositol 3kinase and Rac1 activation facilitates the phagocytosis of Listeria monocytogenes by murine macrophages. Infect Immun 78(6): 2857-2867. doi:10.1128/IAI.01138-09

37. Chuang T, Ulevitch RJ (2001) Identification of hTLR10: a novel human Toll-like receptor preferentially expressed in immune cells. Biochim Biophys Acta 1518(1-2):157-161

38. Bell MP, Svingen PA, Rahman MK, Xiong Y, Faubion WA Jr (2007) FOXP3 regulates TLR10 expression in human T regulatory cells. J Immunol 179(3):1893-1900 
39. Otte JM, Cario E, Podolsky DK (2004) Mechanisms of cross hyporesponsiveness to Toll-like receptor bacterial ligands in intestinal epithelial cells. Gastroenterology 126(4):1054-1070

40. McClure R, Massari P (2014) TLR-dependent human mucosal epithelial cell responses to microbial pathogens. Front Immunol 5: 386. doi:10.3389/fimmu.2014.00386

41. Mikacenic C, Reiner AP, Holden TD, Nickerson DA, Wurfel MM (2013) Variation in the TLR10/TLR1/TLR6 locus is the major genetic determinant of interindividual difference in TLR1/2-mediated responses. Genes Immun 14(1):52-57. doi:10.1038/gene.2012.53

42. Oosting M, Cheng SC, Bolscher JM, Vestering-Stenger R, Plantinga TS, Verschueren IC, Arts P, Garritsen A, van Eenennaam H, Sturm P, Kullberg BJ, Hoischen A, Adema GJ, van der Meer JW, Netea MG, Joosten LA (2014) Human TLR10 is an anti-inflammatory patternrecognition receptor. Proc Natl Acad Sci U S A 111(42):E44784484. doi:10.1073/pnas.1410293111

43. Blander JM, Sander LE (2012) Beyond pattern recognition: five immune checkpoints for scaling the microbial threat. Nat Rev Immunol 12(3):215-225. doi:10.1038/nri3167
44. Sander LE, Davis MJ, Boekschoten MV, Amsen D, Dascher CC, Ryffel B, Swanson JA, Muller M, Blander JM (2011) Detection of prokaryotic mRNA signifies microbial viability and promotes immunity. Nature 474(7351):385-389. doi:10.1038/nature10072

45. Nagashima H, Iwatani S, Cruz M, Jimenez Abreu JA, Uchida T, Mahachai V, Vilaichone RK, Graham DY, Yamaoka Y (2015) Tolllike receptor 10 in Helicobacter pylori infection. J Infect Dis 212(10):1666-1676. doi:10.1093/infdis/jiv270

46. Donato TC, Baptista AA, Garcia KC, Smaniotto BD, Okamoto AS, Sequeira JL, Andreatti Filho RL (2015) Effects of 5hydroxytryptophan and m-hydroxybenzylhydrazine associated to Lactobacillus spp. on the humoral response of broilers challenged with Salmonella enteritidis. Poult Sci 94(9):2081-2087. doi:10.3382/ps/pev206

47. Biaggini K, Barbey C, Borrel V, Feuilloley M, Dechelotte P, Connil N (2015) The pathogenic potential of Pseudomonas fluorescens MFN1032 on enterocytes can be modulated by serotonin, substance P and epinephrine. Arch Microbiol 197(8):983-990. doi:10.1007 /s00203-015-1135-y 